\title{
Research on Innovative Talent Training Pattern of Home Economics
}

\section{Dongmei Sun}

\author{
School of humanities, Jilin Agricultural University, Jilin 130118, China \\ sundongmei-1975@qq.com
}

\begin{abstract}
The article introduce the way to strengthen the research in domestic science of professional theory and practice in colleges and universities, the way to cultivate innovative talents of high quality, the way to establish professional training objectives, the way to set up scientific and reasonable teaching content, the way to obtain employment direction, and then cultivate professional, highquality innovative talents for family services. Discussing home economics innovation personnel training mode not only helps to develop high-quality housekeeping personnel in colleges and universities, but also help improve family service industry specialization degree, improve the overall level of family services, and satisfy the demand of the society.
\end{abstract}

Keywords: home economics; innovative talent training pattern; domestic service.

\section{Introduction}

Domestic service at home and abroad has become one of the important industries in the tertiary industry, aroused people's great attention. The cultivation of the innovative talents of home economics is to satisfy the talent demand of production, construction, management and service, and contribute to the development of local economy and society. From the analysis of home economics innovative talent demand, innovation talent training pattern of home economics mainly based on training target, curriculum, teacher team construction and practice base construction, then evaluate the social benefits of innovative personnel training of home economics.

\section{Demand analysis of innovative talent training pattern of home economics}

With China's economic and social development and the speeding up of popularization of higher education, the demand for innovative talents is increasing. And the emergence of "structural unemployment" phenomenon, at present stage, reflects the fact that colleges and universities are lack of the ability of training innovative talents. In contrast to college students' employment problem, domestic service industry is developing very fast, and domestic service staff with high degree often get the favor of the employer. "Aging society" coming ahead of time will generate many special requirement on social security and education, the elderly and children are the important group need to be taken good care of by the social, family and others. At present, domestic service personnel's own quality, the service level and service quality have a certain gap with the market demand, and the high quality, highly skilled senior local domestic workers is very rare. Domestic service personnel at present stage is mainly rural surplus labor force, urban laid-off workers and unemployed, more is given priority to with $30 \sim 50$ years old women, their level of education is low, the work is focused on primary housekeeping works such as caring for the old man, children, cleaning the room, this is what we usually call the nanny. Senior housekeeping personnel's work includes some advanced domestic work such as family finances, home health care, family psychological counseling, and preschool education and so on, the demand for advanced domestic talent show clear rising trend. Now that the urgency of the demand and the lack of talent put forward the new challenges of the innovative talent training pattern of home economics in our country.

\section{Definition and characteristics of Home economics innovative talents}

Home economics innovative talent refers to the people who are full of pioneering, creative ability, can create a new situation, to make creative contributions to the development of home economics. 
They usually show the individual character of flexible, open, curious, energetic, persistence, concentration, imagination and the characteristics of adventurous spirit,etc.

They usually have the following several characteristics: (1) have a strong curiosity and desire for knowledge; (2) have a strong self-learning and exploring ability; (3) have wide knowledge and higher professional level in the home economics; (4) have a good moral accomplishment, are able to work with others; (5) have a healthy body and good psychological quality, can bear hard work condition.

\section{The status quo of home economics talent cultivation in colleges and universities}

At present, the domestic education is still in its primary stage, the specification of home economics education has not been established yet. Colleges and universities still need to cultivate specialized talents, popularize the domestic theory. Domestic education in the stage of undergraduate is to "touch stone across the river", which obviously can't guarantee to meet the demand of the market. September 2012, the ministry of education officially issued and implemented the catalogue of professional undergraduate course of common colleges and universities, for the first time treat home economics as a special professional undergraduate course and add it in college course specialized new directory. It shows that the home economics in our country enters into the regularization of the trajectory, add new content to the development of higher education as well. Universities and colleges should seize this opportunity, do a good job in home economics major actively, and strive to become a leading domestic and demonstration in talent training.

\subsection{Universities need to set up home economics courses}

With China's urban population birth peak and aging tendency of population, demand of domestic service talented person is very urgent. Statistics show that, in 70 million urban families, more than $70 \%$ of families need domestic service. In the domestic practitioners surveyed, urban laid-off, jobtransfer staff account for 50 percent, whose education background is just junior middle school account for 60 percent, people are more than 40 years old account for 70 percent, most of them with a low cultural level, they are old and lack corresponding vocational skills. Our country need high level cultural domestic service personnel, with high quality and professional skills.

\subsection{Set up the home economics major in colleges consistent with the international domestic discipline}

The development history of domestic discipline has experienced more than 170 years in foreign country. International society of housekeeping held totally 25 annual meeting since it was founded in 1980, but our country has not yet been one of the members. International home economics education is developing rapidly, America, Japan, northern Europe, the Philippines and China's Hong Kong and Taiwan have set up a complete home economics education system. In the United States, there are 780 universities with the Department of Home Economics, some still can be conferred the doctor's and master's degree. However, home economics education in our country is still in its infancy, its scale, quantity and level of development level is relatively backward. We can't achieve the goal of building cultural power and education power country.

\subsection{It is a traditional inheritance and innovation of domestic higher education in our country to open the course of home economics in universities and colleges}

In the early 19th century, universities in our country had opened the course of home economics. In 1919, Beijing Junior Women Normal University formally set up housekeeping department and began to recruit students. From then on, 11 universities have opened the housekeeping department in succession, which are Yanjing University, Northeastern University, Furen University, University of Sinian, Hebei Women's Normal College, Jinling Women's University, south China Women's University and so on. Colleges and universities adjusted the college courses in the 1950s, cancelled the housekeeping department, so that domestic higher education suspended for more than 30 years, from the sense of cultural inheritance, this is a historical regret. 


\subsection{Opening home economics course is an effective way to create their own school-running feature for colleges and universities}

Colleges and universities has been playing a key and active promoter role in home economics professional development history and reality. In many colleges and universities abroad, domestic science not only keep the new generation and built to last, but also stand out, keep unique and become a school signs of professional characteristics, which attract a lot of foreign students. Such as the Florida University at United States and Lihua Women's University, Waseda University, Royal Tea Women's University, National University of the Philippines and so on. The level of home economics major is high in Taiwan furen University, the Hong Kong Institute of Education and other well-known colleges and universities in our country.

\subsection{Taking domestic talent is with the national standard of domestic education for colleges and universities, which meets the inevitable requirement internationally.}

The 12th International Home Economics Conference was held in Finland in 1972, 42 countries took part in the activity without Chain. Home Economics Conference proposed an idea that " Domestic Compulsory Education needs to be implemented in all the school education of teenagers ", to carry out this spirit, some Asian countries such as Japan, South Korea, the Philippines and so on, set home economics course in primary and secondary schools, some countries such as Britain, Germany, the United States also set the housekeeping department in universities and colleges, they also provide master's and doctor's Degree for students who finally finish their study. Home Economics Education is attracting the attention of countries all over the world, because it is related to the human progress and the development of the society. But Home Economics Education in our country is still in its infancy, its development scale and hierarchy level is relatively low. We need to work hard in case we fall behind such countries.

Therefore, colleges and universities should be guided by market demand, clear training objectives, focus on cultivating domestic research workers and housekeeping operations managers with high housekeeping skills and advanced domestic knowledge.

\section{The path of training professional home economics innovative talents}

\subsection{Government's support}

Government support housekeeping personnel training by means of financial support and political favor. Domestic colleges and universities is the cradle of housekeeping personnel training, domestic colleges and universities can be relatively systematic in cultivating professional talents of housekeeping. Our country should give domestic colleges and universities financial support, construct and improve the condition of domestic professional training rooms as needed, invest the housekeeping skills competition activities, set up the entrance scholarship and various kind of domestic scholarship, encourage students to take the examination of Home economics courses. Housekeeping companies function as housekeeping personnel transfer window, so the state should give preferential policy to support its stable development.

\subsection{Vocational colleges and universities cultivate domestic talents}

Schools and teachers need to work together to foster domestic talents. Colleges and universities need to provide a variety of learning opportunities, and provide free funds for teachers to get learning opportunities as well. Colleges and universities also need to provide sufficient training equipment and training materials to strengthen teacher's practical skills.

\subsection{Enterprises should provide professional training programs for college students}

The main purpose of the enterprise training is to meet the needs of the customer's family Each family has a different family life, so the housekeeping work differs with different family, domestic companies need to provide relative matching domestic service for domestic workers, to make them build confidence in the work, learn all kinds of housekeeping skills, at the same time, domestic companies managers will often have returning visits to give college students instruction on their work, especially in the early stage of the work. 


\subsection{Strengthen publicity to create a great atmosphere}

Housekeeping personnel training need positive propaganda from the public media. The media should make everyone in our country know that domestic professional plays an important part in our life today. There can be a number of ways of publicity, such as interviews, reports the good work of the domestic workers, introduce their life in the city, tell the society their hard work, win more social respect and understanding and support.

\section{Summary}

In a sense, the family is a microcosm of the society, social problems are often reflected in the family, any practice that does not pay attention to family is not desirable. There are a variety of diversity means to solve the problem of family, home economics education is the sum total of all kinds of methods.

\section{Acknowledgments}

The work was financially supported by"Jilin province higher education teaching reform project in 2014","Jilin province education science "twelfth five-year" plan project (GH150200)".

\section{References}

[1]. Ling Lin, Lei Guan. Demonstrate the necessity and feasibility of college student home economics education. Science of Social Psychology. Vol. 04 (2006), p. 67-70.

[2]. Qing Li. Research the development of modern home economics from the history of China's domestic education. Vocational Education Research. Vol. 09 (2006), p, 179-180.

[3]. Dongmei Sun, Yafeng Zhou. Research on the localization of home economics in China. Journal of Changchun University of Technology (Social Sciences Edition). Vol. 03 (2010), p, 61-63.

[4]. Ronglian Li. Research on the talents training goal of home economics for China's universities at present. New Campus. Vol. 03 (2015), p, 107-108.

[5]. Zhihui Luo. Explore on professional talent training mode of home economics. Theory Research. Vol. 24 (2015), p, 160-162. 